\title{
forthcoming meetings
}

International Conference on Magnetism and Magnetic Materials (EMMA), September 6-9, 1989, Rimini, Italy. (For information write to EMMA '89, Instituto MASPEC, Via Chiavari, 18/A, 43100 Parma, Italy.)

5 th International Conference on Magnetic Fluids, September, 1989, Riga, Latvia (USSR). (For information write to Professor E. Blums, Institute of Physics, Latvian SSR Academy of Sciences, 229021 Riga, Salaspils, U.S.S.R.)

34 th Annual Conference on Magnetism and Magnetic Materials, Sheraton Boston Hotel and Towers, Boston, Ma., November 28-December 1, 1989. (For information write to Diane Suiters, Conference Coordinator, 655-15th Street, N.W., Suite 300, Washington, D.C. 20005.) 